551.578 .11

\title{
The Frequency Distribution of Rainfall of Different Intensities
}

\author{
by I. Subbaramayya and N. Jaganmohana Rao \\ Department of Meteorology and Oceanography \\ Andhra University, Waltair, India \\ (Communicated by Prof. R. Ramanadham) \\ (Manuscript received 15 May 1964)
}

\begin{abstract}
The frequency distribution of rainfall of different intensities in different parts of the country is studied. The distribution is found to be hyperbolic in all the cases. The equation $y=a /(x+c)+b$, where $x$ is the rainfall per day, $\mathrm{y} \mathrm{dx}$ is the frequency of rainfall and $a, b$ and $c$ are constants, is very satisfactorily found to fit into the data. A theoretical method is developed to evaluate the constants $a, b$ and $c$ from the rainfall amount and the number of rainy days.

The equation is also applied to daily rainfall data of individual stations and the fit is found to be correct by more than $90 \%$ accuracy and it is finally suggested that the equation may be applicable for rainfall in any part of the globe.
\end{abstract}

\section{Introduction}

An idea of how the rainfall at any place s distributed according to the intensity is very important and some meteorologists have made investigations on that line. To mention a few note worthy investigations, Ashmore (1944) studied the contribution to the total rainfall by the Wettest ' $\mathrm{n}$ ' days $(7,12,15$, $20,30,40,50$ and 60 ) at a station in Wrexham District (U. K.). He found that most of the rainfall is derived from only a few heavy falls. He suggested the relation $P=\sqrt{90 \mathrm{n}-300}$ to hold good for that data, where $P$ is the percentage of annual rainfall and $n$ is the number of wettest days. Olascoaga (1950) studied on similar lines the rainfall distribution in a number of regions in Argentina. He found that the skewness of rainfall distribution of different regions to be the same, inspite of the fact that the regions lie in different climatic regimes ranging from arid to humid. He suggested the equation $Y=a x e^{b x}$, where $Y$ is the cumulative percentage rainfall and $x$ is the cumulative percentage rainy days while $a$ and $b$ are constants, which may have a general validity round the globe. Riehl (1950) also made similar studies on the Puerto Rico rainfall to understand the skewness of the rainfall distribution.

In India such studies are very meagre. Doraiswami Iyer and Zafar (1937) have prepared the maps of frequency of occurrence of falls of $3^{\prime \prime}$ and above, and $5^{\prime \prime}$ and above. Later Rao (1958) presented similar maps for $10^{\prime \prime}$ and above falls. Ramakrishnan (1953 a, $1953 \mathrm{~b}, 1955)$ has presented the tabulated data of frequency of occurrence of rainfall of different intensities for 3 stations. Here the intensity refers to the amount of rainfall per day.

The authors with the aim of understanding how the rainfall frequency is distributed in different intensities, in different parts of India, the present investigation is carried out.

\section{Method of analysis}

The country receives most of the annual rainfall during the summer monsoon (southwest monsoon) season as such the daily rainfall in this season (July and August) only is examined in the present investigation. 


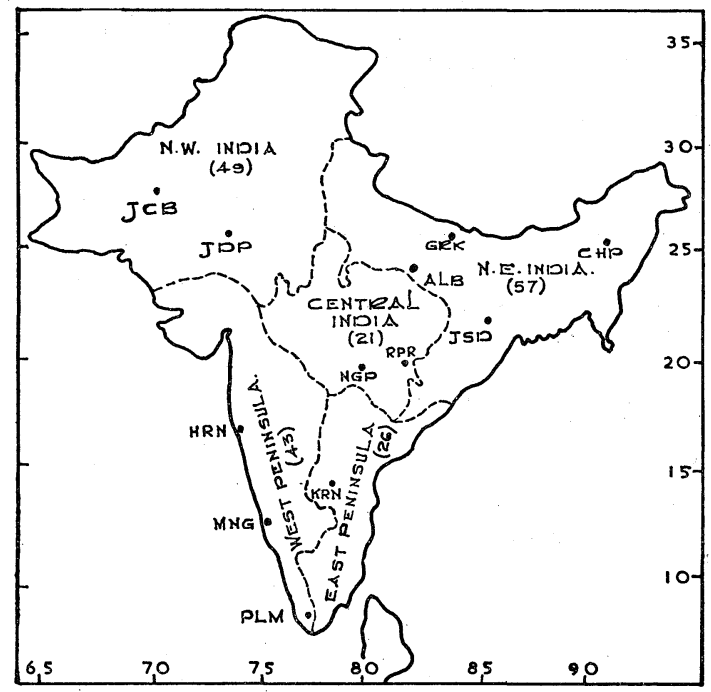

Fig. 1. The numbers in the brackets are the number of observatory stations in each region.

$\begin{array}{ll}\text { CHP-Cherrapunji. } & \text { JSD-Jamshedpur. } \\ \text { GRK-Gorakhpur. } & \text { ALB-Allahabad. } \\ \text { JDP-Jodhpur. } & \text { JCB-Jacobabad. } \\ \text { RPR-Raipur. } & \text { NGP-Nagpur. } \\ \text { HRN-Harnai. } & \text { MNG-Mangalore. } \\ \text { PLM-Palayamkotai. } & \text { KRN-Kurnool. }\end{array}$

The whole country including Pakistan is divided into five regions as shown in Figure 1. (The number of observatory stations in each region are entered on the same figure). The division of the subcontinent is made on the basis of the geographical and meteorological differences from region to region. North-west India is the region of least rains. Heavy rain occurs in North-east India and it is controlled by the Monsoon trough. West Peninsula is the region where the monsoon first hits the country while the partly dessicated monsoon travels over East Peninsula. Some parts of Peninsula and North-east India have the influence of the oceans while Central and North-west India are barred from such influence.

The intensity of rainfall ( $24 \mathrm{hrs}$. rainfall) is divided into 8 class intervals, namely, less than $1 \mathrm{~mm}$., $1-5 \mathrm{~mm}$., $5 \mathrm{~mm} .-1 \mathrm{~cm} ., 1-2 \mathrm{~cm}$., $2-4 \mathrm{~cm} ., 4-8 \mathrm{~cm}$., and greater than $8 \mathrm{~cm}$. The daily rainfall amounts at all the stations in each region for the years 1959 and 1960 are classified to obtain the frequency of rainfall in each class interval. The frequency distri- butions are presented in the form of histograms drawn such that the areas are proportional to the frequencies.

\section{The frequency distributions}

The histograms (Fig. 2) show that the frequency of low intensity rainfall is high and high intensity rainfall is small. The total frequency of observations is different from region to region since the number of stations as well as the number of rainy days at the stations are different. These differences do not permit a proper comparison of the frequency distributions. The percentage frequencies on the other hand allow a comparative study of the distributions. As such, the percentage frequencies are computed and presented in Table 1. It is very interesting to note that the frequency distributions are nearly the same for all the regions. However, there are a few significant, though small, deviations in East Peninsula and North-east India from the general distrubion over the country at large. Low intensity falls are more frequent in the former region while heavier falls are more in the latter. If we ignore these small deviations the percentage frequency distributions are nearly the same in all the regions. This conclusion is similar to that of Olascoaga (1950).

The histograms (Fig. 2) suggest that the frequency distribution of rainfall of different intensities, can be represented bv a function of the form:

$$
y=a /(x+c)+b,
$$

where $a, b$ and $c$ are constants, $x$ is the intensity of rainfall and $y$ is the ordinate such that $\int_{x_{1}}^{x_{2}} y d x$ is the frequency of occurrence of rainfall, and $\int_{x_{1}}^{x_{2}} y x d x$ is the precipitation due to rainfalls of intensities between $x_{1}$ and $x_{2}$.

The constants $a, b$, and $c$ can be evaluated from the total rainfall and the number of rainy days in the season. Let $x_{0}$ be the point on the $x$-axis where the frequency distribution curve cuts the $x$-axis. Then,

$$
0=a+b\left(x_{0}+c\right) \text {. }
$$

The total number of rainy days 


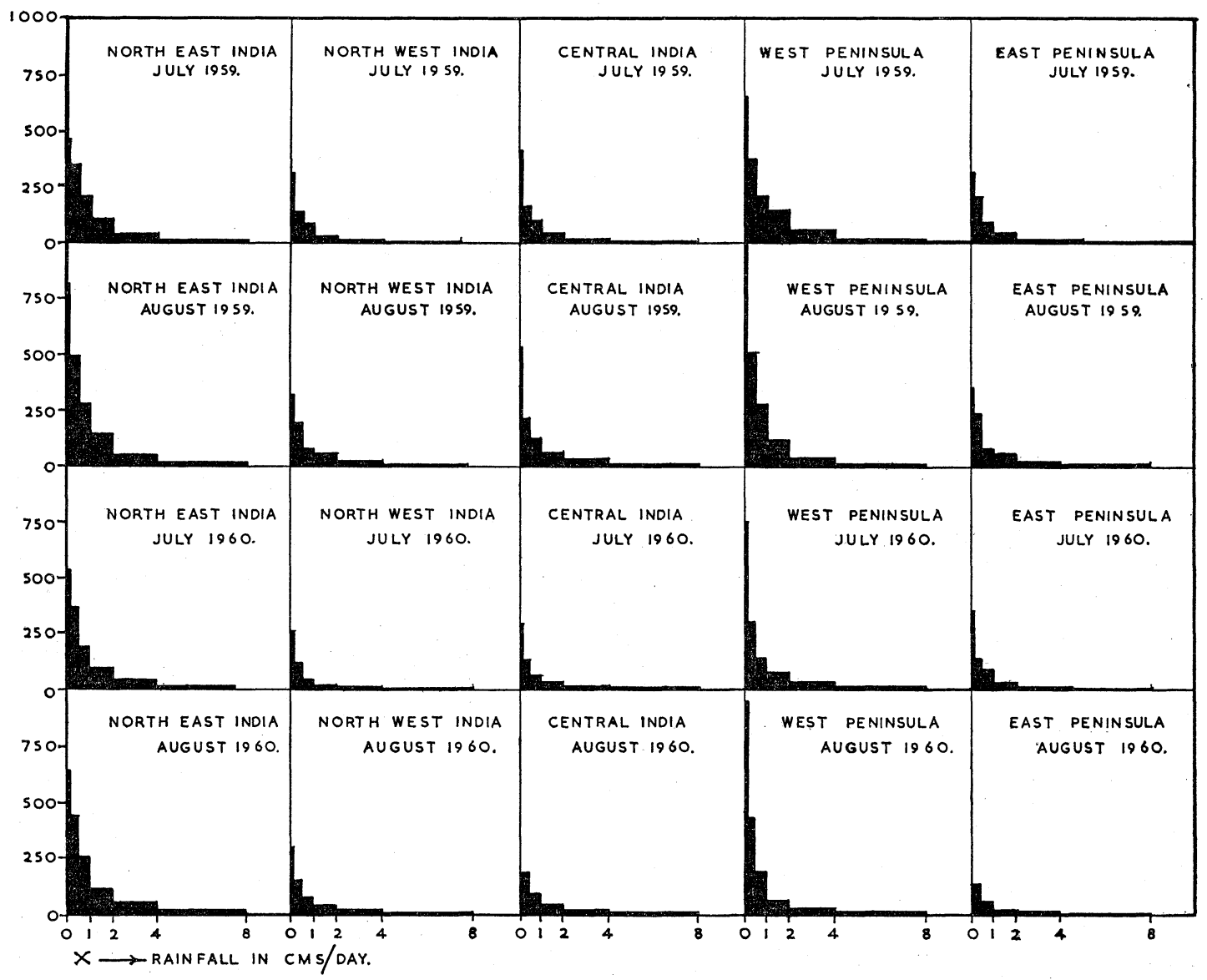

Fig. 2. Frequency distribution of rainfall.

Area $=$ Hundred occurrences.

Table 1 Percentage frequencies

\begin{tabular}{|c|c|c|c|c|c|c|c|c|c|c|c|}
\hline \multirow{2}{*}{$\begin{array}{l}\text { Rainfall } \\
\text { Rain in } \mathrm{cm} .\end{array}$} & \multicolumn{2}{|c|}{$\begin{array}{l}\text { North-east } \\
\text { India }\end{array}$} & \multicolumn{2}{|c|}{$\begin{array}{l}\text { North-West } \\
\text { India }\end{array}$} & \multicolumn{2}{|c|}{$\begin{array}{l}\text { Central } \\
\text { India }\end{array}$} & \multicolumn{2}{|c|}{$\begin{array}{c}\text { West } \\
\text { Peninsula }\end{array}$} & \multicolumn{2}{|c|}{$\begin{array}{c}\text { East } \\
\text { Peninsula }\end{array}$} & \multirow{2}{*}{$\begin{array}{l}\text { Mean percen- } \\
\text { tage frequences }\end{array}$} \\
\hline & $\begin{array}{l}\text { July } \\
1959\end{array}$ & $\begin{array}{l}\text { Aug. } \\
59\end{array}$ & $\begin{array}{c}\text { July } \\
59\end{array}$ & $\begin{array}{c}\text { Aug. } \\
59\end{array}$ & $\begin{array}{c}\text { July } \\
59\end{array}$ & $\begin{array}{c}\text { Aug. } \\
59\end{array}$ & $\begin{array}{c}\text { July } \\
59\end{array}$ & $\begin{array}{c}\text { Aug. } \\
59\end{array}$ & $\begin{array}{c}\text { July } \\
59\end{array}$ & $\begin{array}{c}\text { Aug. } \\
59\end{array}$ & \\
\hline $0.0-0.1$ & 6.98 & 10.91 & 14. 42 & 12.80 & 16. 02 & 14. 48 & 9.57 & 15.70 & 13.22 & 12.86 & 12.69 \\
\hline $0.1-0.5$ & 26.77 & 25.75 & 26.52 & 27.33 & 25.00 & 23. 78 & 21.80 & 29.25 & 34.71 & 33.83 & 27.47 \\
\hline $0.5-1.0$ & 20.77 & 18.27 & 20.00 & 13. 55 & 19. 54 & 17.49 & 14.68 & 19. 59 & 19. 43 & 14.71 & 17.38 \\
\hline 1. $0-2.0$ & 20.46 & 19.45 & 13. 02 & 21.80 & 16. 80 & 16.93 & 21.06 & 16. 14 & 17.77 & 20.22 & 18.36 \\
\hline 2. $0-4.0$ & 16.25 & 15.11 & 12.10 & 15.57 & 10.94 & 16.66 & 15.76 & 10.95 & 9.50 & 13. 23 & 13.60 \\
\hline 4. $0-8.0$ & 5.54 & 18. 01 & 11.62 & 7.26 & 8.98 & 9.06 & 12.08 & 5.19 & 4. 13 & 3. 67 & 7.55 \\
\hline$>8.0$ & 2.10 & 2.50 & 2.32 & 1.73 & 2.73 & 1.64 & 4.71 & $3.17 \mid$ & 1.24 & 0.73 & 2.28 \\
\hline
\end{tabular}


Table 1 (Contd.)

\begin{tabular}{|c|c|c|c|c|c|c|c|c|c|c|c|}
\hline \multirow{2}{*}{$\begin{array}{l}\text { Rainfall } \\
\text { Rain im } \mathrm{cm} \text {. }\end{array}$} & \multicolumn{2}{|c|}{$\begin{array}{l}\text { North-east } \\
\text { India }\end{array}$} & \multicolumn{2}{|c|}{$\begin{array}{l}\text { North-West } \\
\text { India }\end{array}$} & \multicolumn{2}{|c|}{$\begin{array}{c}\text { Central } \\
\text { India }\end{array}$} & \multicolumn{2}{|c|}{$\begin{array}{c}\text { West } \\
\text { Peninsula }\end{array}$} & \multicolumn{2}{|c|}{$\begin{array}{c}\text { East } \\
\text { Peninsula }\end{array}$} & \multirow{2}{*}{$\begin{array}{l}\text { Mean percen- } \\
\text { tage frequencies }\end{array}$} \\
\hline & $\begin{array}{c}\text { July } \\
60\end{array}$ & $\begin{array}{c}\text { Ang. } \\
60\end{array}$ & $\begin{array}{c}\text { July } \\
60\end{array}$ & Aug. & $\begin{array}{c}\text { July } \\
60\end{array}$ & $\begin{array}{l}\text { Aug. } \\
60\end{array}$ & $\begin{array}{l}\text { July } \\
60\end{array}$ & $\begin{array}{c}\text { Aug. } \\
60\end{array}$ & $\begin{array}{c}\text { July } \\
60\end{array}$ & $\begin{array}{c}\text { Aug. } \\
60\end{array}$ & \\
\hline $0.0-0.1$ & 9.59 & 8.81 & 15.57 & 13.06 & 14.50 & 15.94 & 15.70 & 18.61 & 17.24 & 20.40 & 14.94 \\
\hline $0.1-0.5$ & 26.23 & 25.14 & 29.94 & 27.03 & 26.00 & 27.69 & 25.11 & 33.86 & 29.07 & 36.74 & 28.68 \\
\hline $0.5-1.0$ & 16.88 & 17.77 & 14.37 & 16.66 & 15.00 & 15.77 & 14.02 & 18. 06 & 21.68 & 19.72 & 16.99 \\
\hline 1. $0-2.0$ & 17.58 & 16. 33 & 14.97 & 18.91 & 20.00 & 16.15 & 15.70 & 14. 06 & 15.76 & 14. 29 & 16.37 \\
\hline 2. $0-4.0$ & 16.88 & 17.61 & 13.90 & 15.31 & 15.00 & 8. 86 & 22.88 & 9.68 & 9.85 & 6.80 & 13.68 \\
\hline 4. $0-8.0$ & 10.48 & 10.79 & 5.71 & 7.22 & 5.60 & 7. 31 & 10.25 & 4.75 & 5.42 & 1.36 & 6.89 \\
\hline$>8.0$ & 2. 31 & 2.70 & 4.19 & 1.80 & 3.50 & 2. $31_{\mid}$ & 4. 81 & 0.08 & 0.99 & 0.08 & 2.28 \\
\hline
\end{tabular}

$$
\begin{aligned}
N & =\int_{0}^{x_{0}}\left(\frac{a}{x+c}+b\right) d x \\
& =b x_{0}+a \log \left(x_{0}+c\right) / c .
\end{aligned}
$$

The total rainfall

$$
\begin{aligned}
R & =\int_{0}^{x_{0}}\left(\frac{a}{x+c}+b\right) x \cdot d x \\
& =a x_{0}+b x^{2}{ }_{0} / 2-a c \log \left(x_{0}+c\right) / c .
\end{aligned}
$$

It ' $z$ ' is defined as the product of $y$ and $x$ then the curve $Z$ versus $x$ would be the rainfall distribution curve. The area bounded by the curve and the $x$-axis is the total rainfall and the area between the curve, $x$-axis and any two ordinates (say at $x_{1}$ and $x_{2}$ ), is the precipitation contributed by the falls of the intensities that lie between $x_{1}$ and $x_{2}$. The rainfall distribution curve invariably shows a maximum where $x=R / N$. It means, the maximum contribution to the total rainfall is made by the falls whose intensities are in the vicinity of the average rainfall per day. Imposing this condition on the rainfall distribution curve, $d z / d x=0$, when $x=R / N$, and

$$
b=-a c N^{2} /(R+N c)^{2} .
$$

The values of the four unknowns $a, b, c$ and $x_{0}$ can be obtained from the above four equations, but the evaluation is by no means simple. The following equation can be obtained by eliminating $a$ and $b$ from the equations (2), (3) and (4)

$$
R+N c=\frac{N x^{2}{ }_{0} / 2}{\left(x_{0}+c\right)\left\{-\frac{x_{0}}{x_{0}+c}+\log \frac{x_{0}+c}{c}\right\}} .
$$

For the purpose of convenience, $N$ is made 100 and the corresponding value of $R$, denoted as $r$, can be obtained from the given data of $R$ and $N$, from the expression $(R / N) 100$. Now the equation (6) may be written as:

$$
r=100\left[\frac{x_{0}^{2} / 2}{\left(x_{0}+c\right)\left\{-\frac{x_{0}}{x_{0}+c}+\log \frac{x_{0}+c}{c}\right\}}-c\right]
$$

The values of $r$ for a given value of $x_{0}$ say 16 and different values of $c$, are computed from equation (7). A graph, $r$ versus $c$ is drawn. Similarly a set of graphs, $r$ versus $c$ for different values of $x_{0}(1,2,4,8,16,32,64$ and 128) are drawn as shown in Fig. 3 (lines sloping down towards left). The value of $c$ corresponding to the value of $r$ got from the observations, can be obtained from these graphs, but it has different values depending on $x_{0}$.

From equations (2) and (5) it can be written as

$$
c=r^{2} / 100\left(100 x_{0}-2 r\right) .
$$

Again a set of values of $c$, for a given value of $r$ and different values of $x_{0}(1,2,4 \cdots \cdots 128)$ are obtained. The values of $c$ for different values of $r$, are likewise calculated. A set of graphs, $c$ versus $x_{0}$ are drawn on the same Fig. 3 (curves sloping down towards right) for different values of $r$. There would be one point on every graph of this set which satisfies the scale on the $y$-axis. All such points are joined and the line $A B$ is obtained. Every point on this line satisfies the equations (2), (3), (4) and 5. The values of $x_{0}$ and $c$ can be obtained from this figure, for any given value of $r$. 


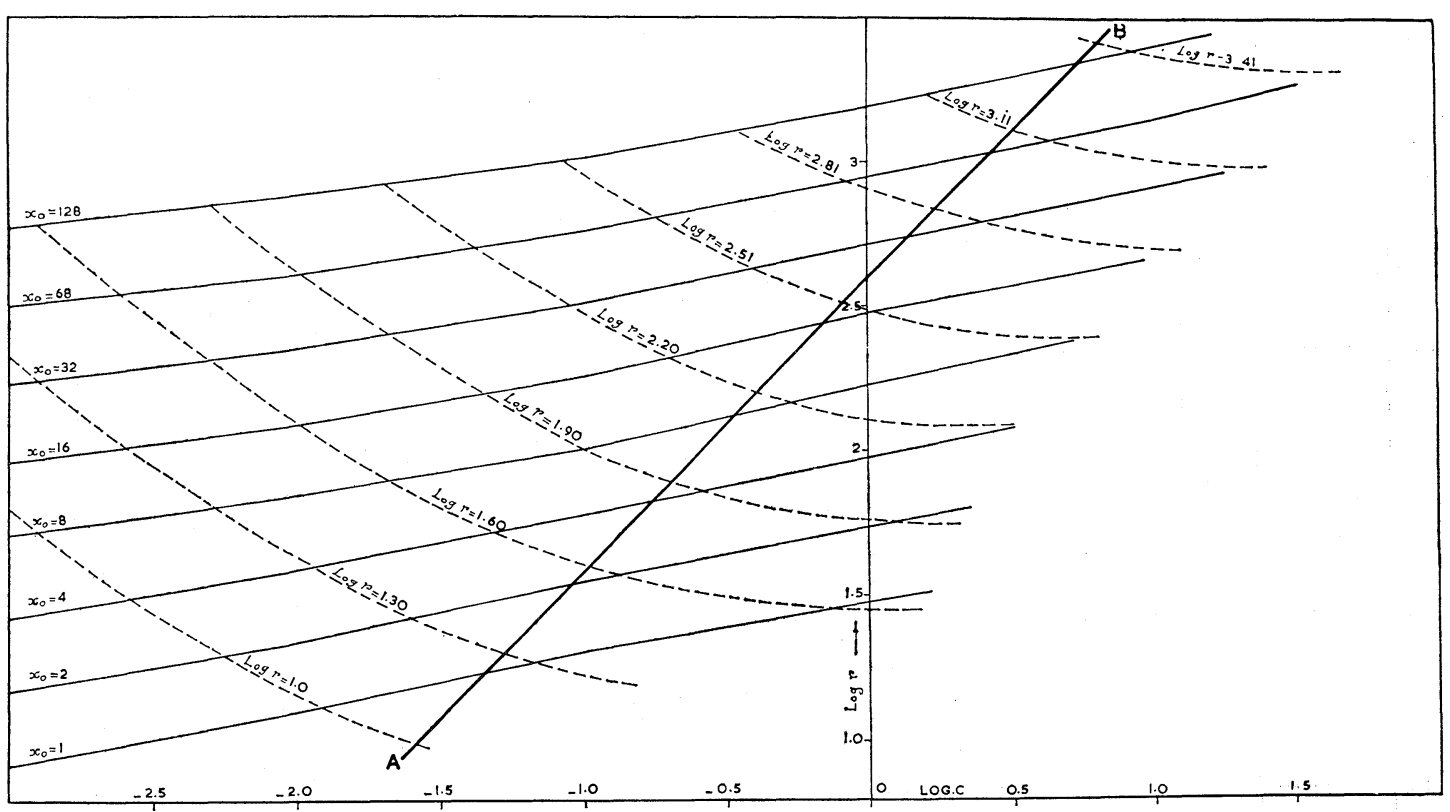

Fig. 3. Graphical solution of the equations (2), (3), (4), and (5).

Thence the value of $b$ and $a$ can be evaluated from the equations (9) and (10) respectively which are obtained from (2), (3) and (4) by proper eliminations, i. e.,

$$
\begin{aligned}
& b=-2(R+N c) / x_{0}{ }^{2}, \\
& a=2\left(x_{0}+c\right)(R+N c) / x_{0}{ }^{2} .
\end{aligned}
$$

There would be a little difficulty in estimaing the value of $x_{0}$ from Fig. 3 for any value of $r$. Hence $r$ is estimated for particular values of $x_{0}(1,2,4, \cdots \cdots 128)$, which is easy and accurate and then Fig. 4 is prepared. This figure in turn makes the estimation of $x_{0}$ simple and accurate, for any value of $r$. On the same graph the values of $c$ and $-b$ are also plotted against $r$, so that $x_{0}, c$ and $b$ can be readily read off from Fig. 4 ( $r$ may be either in inches or cms.) It is evident from the graphs that there is a linear relation between $x_{0}, b$ and $c$ and $r$. The constant $a$ is found to be independent of $r$ and takes the value 44.5. The frequency distribution function $y=a /(x+c)+b$ is now applied to the AllIndia rainfall data presented in the last column of Table 1. The observed and the calculated frequencies are given in Table-II. There is a good agreement between the two.

The values of $x_{0}, b$ and $c$ can be got, not only from Fig. 4 but also from the below equations which could be obtained because of their linear relation with $r$.

$$
\begin{aligned}
& x_{0}=0.0586 r, \\
& c=0.00253 r, \\
& b=-727.0 / r, \\
& a=44.48 .
\end{aligned}
$$

\section{The frequency distribution of rainfall at selected stations}

The above derived analytical expressions may be applicable for the rainfall data of individual stations. To verify its applicability, the authors have selected twelve stations,

Table 2 Computed and observed percentage frequencies.

\begin{tabular}{c|r|r|r|r}
\hline \multirow{2}{*}{ Range in cm. } & \multicolumn{2}{|c}{$\begin{array}{c}\text { Observed per- } \\
\text { centage } \\
\text { Frequencies }\end{array}$} & \multicolumn{2}{c}{$\begin{array}{c}\text { Computed per- } \\
\text { centage } \\
\text { frequencies }\end{array}$} \\
\cline { 2 - 5 } & \multicolumn{1}{|c|}{1959} & 1960 & \multicolumn{1}{c}{1959} & \multicolumn{1}{c}{1960} \\
\hline $0.0-0.1$ & 12.69 & 14.94 & 9.22 & 9.73 \\
$0.1-0.5$ & 27.47 & 28.63 & 23.88 & 24.73 \\
$0.5-1.0$ & 17.58 & 16.99 & 17.20 & 17.51 \\
$1.0-2.0$ & 18.36 & 16.38 & 19.36 & 19.37 \\
$2.0-4.0$ & 13.60 & 13.68 & 17.92 & 17.54 \\
$4.0-8.0$ & 7.55 & 6.89 & 10.87 & 9.80 \\
$>8.0$ & 2.28 & 2.27 & 0.61 & 0.26 \\
\hline
\end{tabular}




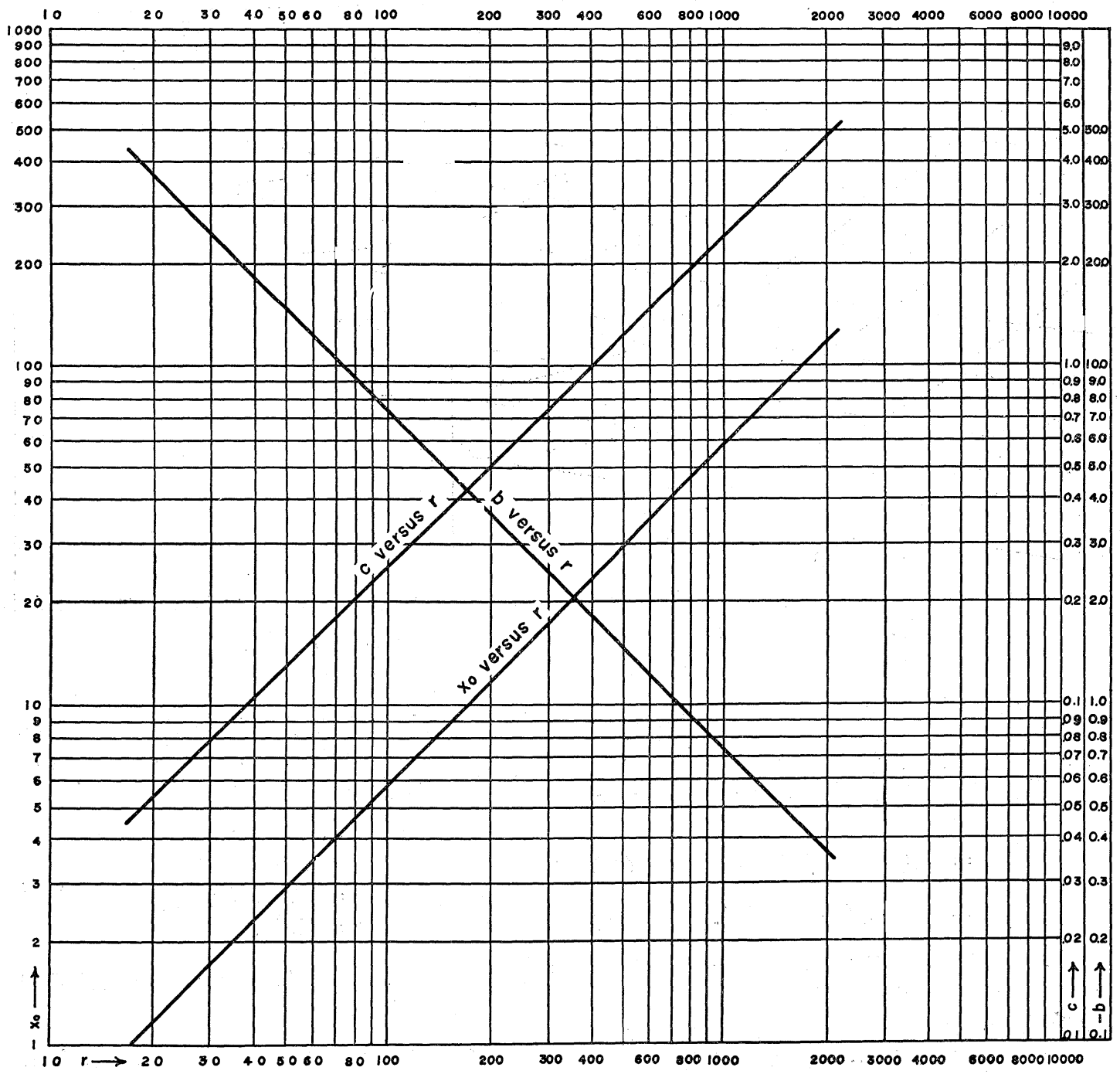

Fig. 4. Nomogram for the estimation of $-b, \dot{c}$; and $x_{0}$ from $r$. The scale on the $y$-axis corresponding to $-b$ and $c$ is given un the right hand side.

that are shown in Fig. 1, such that the seasonal (July and August) rainfall of the stations range from $5 \mathrm{~cm}$. to $300 \mathrm{~cm}$. The daily rainfall data of these stations for 10 years (1954-1963) for monsoon months are classified to obtain the frequencies in different ranges of intensities. Then the percentage frequencies are evaluated and given in Table 3 .

The percentage frequencies are computed using the analytical expressions discussed in the previous section and are presented in Table 3.

The computed values are in general, lower than the observed values, below $0.5 \mathrm{~cm}$./day rainfall, while in the middle ranges the computed frequencies are slightly greater than the observed. There is no significant disparity on the high frequency side. To have a quantitative idea of how best the computed frequencies fit with the observed, the $\chi^{2}$ test is performed for the data of all the stations. The $\chi^{2}$ values are presented in the last column of Table 3. The fit is exceedingly good for the stations Cherrapunji, Jamshedpur, Gorakhpore, Allahabad, Harnai and Mangalore, while that of Jacobabad and Palayamkotai are very poor. Kurnool, Nagpur, Raipur and Jodhpur show satisfactory agreement. The 
Table 3 Percentage frequencies of rainfall for the selected stations

\begin{tabular}{|c|c|c|c|c|c|c|c|c|c|c|c|c|c|c|c|c|}
\hline Sta & $\left|\begin{array}{c}0.0- \\
0.1 \\
\mathrm{~cm}\end{array}\right|$ & $\begin{array}{c}0.1- \\
0.5 \\
\mathrm{~cm}\end{array}$ & $\left|\begin{array}{c}0.5- \\
1.0 \\
\mathrm{~cm}\end{array}\right|$ & $\begin{array}{c}1.0 \\
2.0 \\
\mathrm{~cm}\end{array}$ & $\left|\begin{array}{c}2.0 \\
3.0 \\
\mathrm{~cm}\end{array}\right|$ & $\left|\begin{array}{c}3.0- \\
4.0 \\
\mathrm{~cm}\end{array}\right|$ & $\left|\begin{array}{c}4.0 \\
5.0 \\
\mathrm{~cm}\end{array}\right|$ & $\left|\begin{array}{c}5.0 \\
6.0 \\
\mathrm{~cm}\end{array}\right|$ & $\left|\begin{array}{c}6.0 \\
7.0 \\
\mathrm{~cm}\end{array}\right|$ & $\left|\begin{array}{c}7.0 \\
8.0 \\
\mathrm{~cm}\end{array}\right|$ & $\left|\begin{array}{c}8.0 \\
9.0 \\
\mathrm{~cm}\end{array}\right|$ & $\left|\begin{array}{l}9.0 \\
10.0 \\
\mathrm{~cm}\end{array}\right|$ & $\left|\begin{array}{c}10.0 \\
12.0 \\
\mathrm{~cm}\end{array}\right|$ & $\left|\begin{array}{c}12.0 \\
16.0 \\
\mathrm{~cm}\end{array}\right|$ & $\left|\begin{array}{c}16.0 \\
\mathrm{~cm}\end{array}\right|$ & $\chi^{2}$ Values \\
\hline $\begin{array}{l}\text { Obs } \\
\text { Com }\end{array}$ & $\begin{array}{l}4.15 \\
2.92\end{array}$ & $\begin{array}{r}12.88 \\
9.96\end{array}$ & $\left.\mid \begin{array}{l}8.74 \\
9.64\end{array}\right]$ & $\begin{array}{l}11.35 \\
14.15\end{array}$ & $\begin{array}{r}6.98 \\
10.14\end{array}$ & $\begin{array}{l}7.64 \\
7.79 \\
\end{array}$ & $\mid \begin{array}{l}4.80 \\
6.24\end{array}$ & $\begin{array}{l}8.29 \\
5.14\end{array}$ & $\begin{array}{l}5.24 \\
4.32\end{array}$ & \begin{tabular}{|l|}
3.93 \\
3.75
\end{tabular} & $\begin{array}{l}3.49 \\
3.19\end{array}$ & $\begin{array}{l}2.62 \\
2.78\end{array}$ & \begin{tabular}{|l|}
4.58 \\
4.87
\end{tabular} & $\begin{array}{l}6.51 \\
6.38\end{array}$ & $\begin{array}{l}8.74 \\
8.15\end{array}$ & $\begin{array}{l}.95<\mathrm{P}\left(\chi_{14}^{2}\right. \\
>5.6311)<.98\end{array}$ \\
\hline $\begin{array}{r}\text { Jamshec } \\
\text { Obser } \\
\text { Comp }\end{array}$ & $\left|\begin{array}{l}15.03 \\
10.86\end{array}\right|$ & $\begin{array}{l}17.46 \\
26.51\end{array}$ & $\begin{array}{l}15.81 \\
18.02\end{array}$ & $\begin{array}{l}16.59 \\
19.40\end{array}$ & $\begin{array}{r}9.85 \\
10.44\end{array}$ & $\begin{array}{l}6.48 \\
6.27\end{array}$ & $\begin{array}{l}3.88 \\
3.84\end{array}$ & $\left|\begin{array}{l}3.11 \\
2.28\end{array}\right|$ & $\begin{array}{l}0.78 \\
1.14\end{array}$ & $\begin{array}{l}0.51 \\
0.32\end{array}$ & 0.51 & & & & & $\begin{array}{l}.95<\mathrm{P}\left(\chi_{9}{ }^{2}\right. \\
>2.6887)<.98\end{array}$ \\
\hline $\begin{array}{l}\text { Gorakt } \\
\text { Obse } \\
\text { Com }\end{array}$ & $\mid \begin{array}{r}11.61 \\
8.37\end{array}$ & $\begin{array}{l}23.89 \\
22.40\end{array}$ & $\begin{array}{l}17.06 \\
16.66\end{array} \mid$ & $\begin{array}{l}17.41 \\
19.22\end{array}$ & $\begin{array}{r}9.89 \\
11.06\end{array}$ & $\begin{array}{l}6.82 \\
7.22\end{array}$ & $\begin{array}{l}4.09 \\
4.99\end{array}$ & $\mid \begin{array}{l}2.39 \\
4.51\end{array}$ & $\begin{array}{l}2.73 \\
2.40\end{array}$ & $\begin{array}{l}1.02 \\
1.60\end{array}$ & $\mid \begin{array}{l}1.71 \\
0.95\end{array}$ & $\mid \begin{array}{l}0.68 \\
0.43\end{array}$ & 0.08 & 0.68 & & $\begin{array}{l}.95>\mathrm{P}\left(\chi_{11}{ }^{2}\right. \\
>4.1326)<.98\end{array}$ \\
\hline $\begin{array}{l}\text { Obse } \\
\text { Com }\end{array}$ & $\begin{array}{r}12.94 \\
8.97\end{array}$ & $\begin{array}{l}27.35 \\
23.39\end{array}$ & $\begin{array}{l}15.00 \\
17.03\end{array}$ & $\begin{array}{l}17.94 \\
19.31\end{array}$ & $\begin{array}{r}8.82 \\
11.06\end{array}$ & $\begin{array}{l}7.94 \\
7.09\end{array}$ & $\begin{array}{l}2.94 \\
4.76\end{array}$ & $\begin{array}{l}2.94 \\
3.22\end{array}$ & $\begin{array}{l}2.06 \\
2.13\end{array}$ & $\begin{array}{l}0.29 \\
1.28\end{array}$ & 0.29 & $\mid \begin{array}{l}0.29 \\
0.16\end{array}$ & & 0.59 & 0.59 & $\begin{array}{l}.90<\mathrm{P}\left(\chi_{11}{ }^{2}\right. \\
>5.2216)<.95\end{array}$ \\
\hline Obs & $\begin{array}{l}28.06 \\
13.35\end{array} \mid$ & $\begin{array}{l}28.06 \\
30.90\end{array}$ & $\begin{array}{l}12.28 \\
19.36\end{array}$ & $\begin{array}{l}13.34 \\
18.98\end{array}$ & $\begin{array}{l}8.77 \\
9.42\end{array}$ & $\begin{array}{l}3.51 \\
4.16\end{array}$ & 2.34 & $\begin{array}{l}1.75 \\
0.91\end{array}$ & $\begin{array}{l}1.17 \\
0.04\end{array}$ & & & 0.58 & & & & $\begin{array}{c}.001<\mathrm{P}\left(\chi_{7}{ }^{2}\right. \\
>21.2568)<.005\end{array}$ \\
\hline Obs & $\mid \begin{array}{r}15.61 \\
9.18\end{array}$ & $\begin{array}{l}25.30 \\
23.92\end{array}$ & $\begin{array}{l}17.02 \\
17.22\end{array}$ & $\begin{array}{l}16.55 \\
19.39\end{array}$ & $\begin{array}{r}8.75 \\
10.97\end{array}$ & $\begin{array}{l}5.91 \\
6.96\end{array}$ & $\begin{array}{l}2.84 \\
4.63\end{array}$ & $\begin{array}{l}2.60 \\
3.09\end{array}$ & $\begin{array}{l}2.36 \\
1.98\end{array}$ & $\begin{array}{l}0.95 \\
1.17\end{array}$ & 0.52 & $\begin{array}{l}0.95 \\
0.16\end{array}$ & 0.71 & 0.24 & 0.24 & $\begin{array}{l}.50<\mathrm{P}\left(\chi_{9}{ }^{2}\right. \\
>6.4143)<.70\end{array}$ \\
\hline $\mathrm{Ob}$ & $\begin{array}{l}5.16 \\
6.11\end{array}$ & $\begin{array}{l}19.32 \\
17.90\end{array}$ & $\begin{array}{l}18.35 \\
14.67\end{array}$ & $\begin{array}{l}18.35 \\
18.26\end{array}$ & $\begin{array}{r}9.75 \\
11.40\end{array}$ & $\begin{array}{l}6.12 \\
7.98\end{array}$ & $\begin{array}{l}4.02 \\
5.83\end{array}$ & $\begin{array}{l}4.21 \\
4.413\end{array}$ & $\begin{array}{l}3.06 \\
3.36\end{array}$ & \begin{tabular}{|l|}
3.25 \\
2.62
\end{tabular} & $\begin{array}{l}2.30 \\
2.02\end{array}$ & $\begin{array}{l}1.72 \\
1.51\end{array}$ & $\begin{array}{l}1.91 \\
1.96\end{array}$ & \begin{tabular}{|l|}
2.10 \\
0.82
\end{tabular} & 0.19 & $\begin{array}{l}.95<\mathrm{P}\left(\chi_{13}{ }^{2}\right. \\
>4.6575)<.98\end{array}$ \\
\hline $\begin{array}{l}\text { Nagp } \\
\text { Obs } \\
\text { Cor }\end{array}$ & $\begin{array}{l}15.65 \\
10.75\end{array}$ & $\begin{array}{l}29.65 \\
26.35\end{array}$ & $\begin{array}{l}15.86 \\
17.90\end{array}$ & $\begin{array}{l}16.35 \\
19.41\end{array}$ & $\left|\begin{array}{l}10.39 \\
10.49\end{array}\right|$ & $\begin{array}{l}3.61 \\
5.70\end{array}$ & $\begin{array}{l}3.36 \\
4.89\end{array}$ & $\begin{array}{l}2.16 \\
2.32\end{array}$ & $\begin{array}{l}0.48 \\
1.19\end{array}$ & $\left|\begin{array}{l}0.72 \\
0.36\end{array}\right|$ & 1.44 & 0.48 & & & & $\begin{array}{l}70<\mathrm{P}\left(\chi_{9}{ }^{2}\right. \\
>5.4331)<.80\end{array}$ \\
\hline $\begin{array}{l}\text { Kurno } \\
\text { Obs } \\
\text { Con }\end{array}$ & $\begin{array}{r}9.29 \\
12.31\end{array}$ & $\begin{array}{l}39.99 \\
28.53\end{array}$ & $\begin{array}{l}18.57 \\
18.56\end{array}$ & $\begin{array}{l}15.36 \\
19.23\end{array}$ & $\begin{array}{l}6.07 \\
9.78\end{array}$ & $\begin{array}{l}3.93 \\
5.59\end{array}$ & $\begin{array}{l}2.50 \\
3.11\end{array}$ & $\begin{array}{l}2.14 \\
1.49\end{array}$ & $\begin{array}{l}0.71 \\
1.59\end{array}$ & 0.36 & 0.36 & 0.36 & & 0.36 & & $\begin{array}{l}30<\mathrm{P}\left(\chi_{8}^{2}\right. \\
>8.9136)<.50\end{array}$ \\
\hline $\begin{array}{r}\text { Palaya } \\
\text { Obse } \\
\text { Com }\end{array}$ & $\begin{array}{l}24.24 \\
15.36\end{array}$ & $\begin{array}{l}36.37 \\
32.41\end{array}$ & $\begin{array}{l}15.16 \\
19.21\end{array}$ & $\begin{array}{r}9.09 \\
18.43\end{array}$ & $\begin{array}{l}6.06 \\
8.44\end{array}$ & $\begin{array}{r}6.06 \\
3.93\end{array}$ & $\begin{array}{l}3.03 \\
1.39\end{array}$ & 0.18 & & & & & & & & $\begin{array}{l}10<\mathrm{P}\left(\chi_{6}{ }^{2}\right. \\
>9.9631)<.20\end{array}$ \\
\hline $\begin{array}{r}\mathrm{Man} \\
\mathrm{Ol}\end{array}$ & 3.92 & 14.20 & 12.89 & 23. 33 & 11.40 & 7.29 & 7.85 & 5.79 & 3.74 & 2.62 & 1.87 & 2.62 & 2. 31 & 0.75 & 0.37 & \\
\hline & 4. 29 & 16.18 & 13. 68 & 17.63 & 11.33 & 8.08 & 6.06 & 4.58 & 3.71 & 2.95 & 2.36 & 2.96 & 2.71 & 2.40 & 0.17 & $>4.6974)<.99$ \\
\hline $\begin{array}{l}\text { Jacobabad } \\
\text { Observed : } \\
\text { Computed : }\end{array}$ & $\begin{array}{l}17.14 \\
10.26\end{array}$ & $\begin{array}{l}20.00 \\
25.61\end{array}$ & $\begin{array}{l}25.71 \\
17.78\end{array}$ & $\begin{array}{l}17.14 \\
21.41\end{array}$ & $\begin{array}{r}5.72 \\
10.66\end{array}$ & 2.86 & $\begin{array}{l}8.57 \\
4.14\end{array}$ & & & 0.62 & 0.06 & & & & & $\begin{array}{l}.01<\mathrm{P}\left(\chi_{6}{ }^{2}\right. \\
>16.1395)<.02\end{array}$ \\
\hline
\end{tabular}

significantly high $\chi^{2}$ values obtained for Kurnool and Jodhpur are merely due to the disparity of the frequencies in the class intervals, 0.1 to $0.5 \mathrm{~cm}$. and $0.0-0.1 \mathrm{~cm}$. respectively. Over the rest of the spectra, the agreement is fairly good and the apparent high value for Kurnool and Jodhpur should not be interpreted as a bad fit throughout the spectrum. The poor fit for Palayamkotai and Jacobabad data may be due to the small number of rainy days (33 days) that occured in ten years, while for the rest of the stations the number of rainy days range from 200 to 550 . However the general trend of the goodness of fit seems to increase with heavier rainfall. Thus the equation sug- gested in the present studies represents the frequency distribution of rainfall at places of moderate and heavy rainfall with more than $90 \%$ accuracy.

\section{Conclusions}

1) The frequency distribution has a hyperbolic form showing high frequencies at low rates of rainfall and low frequencies at high rates of rainfall.

2) The general frequency distribution of rainfall over a large area is same in any part of the country.

3) The frequency distribution of rainfall of individual stations or over large areas is very satisfactorily defined by the function 
$y=a /(x+c)+b$.

4) Finally it may be suggested that this expression can be applied to the rainfall data in any part of the globe.

\section{References}

Ashmore, S. E. 1944 : Quart. J. Roy. meteor. Soc. 70, p-241.

Doraisamy Iyer, V. and Zafar Mohamad, 1937 : Sci. Notes. Ind. Meteor. Dept., VII, No. 77, 109118.
Olascoaga, M. J. (1950) : Tellus, 2, No. 4, P-312. Ramakrishnan, K. P. 1953a: Ind. J. Met. Geo., 4, No. 2, p-123.

Ramakrishnan, K.P. and J. Narayanan 1953b : Ind. J. Met. Geo., 4, No. 4, p-310.

Ramakrishnan, K. P. and J. Narayanan 1955: Mem. Ind. Met. Dept., 30, 101-153.

Rao, K. N. 1958: Symposium on meteorological and hydrological aspects of floods and droughts in India, New Delhi, 11-14, (Pub. Ind. Meteo. Dept.).

Riehl, H. 1950: Tellus, 2, No. 1, p-1.

\title{
種々の強さの降雨度数分布
}

\author{
I. スバラマヤ, N. ヤガンモハナ・ラオ \\ アンドレ大学気象学海洋学部, インド
}

\footnotetext{
インド各地の種々の強さの降雨の度数分布を調べた。分布はどの場合でも双曲型であることが分った。 量, $y d x$ を降雨の度数, $a, b, c$ を常数とすると $y=a /(x+c)+b$ がデータと非常によく合うことが見出された。 雨量と降雨日数とから常数 $a, b, c$ の値を求める理論的方法を考光た。

この式を個々の観測所の日雨量飞ああてはめて見たところ，90\% 以上の精度で合うことが分った。結局この式は 地球上のどの部分にも適用できそうである。
} 